\begin{tabular}{|c|l|}
\hline Title & $\begin{array}{l}\text { MRLMpJ mice produce more oocytes and exhibit impaired fertilisation and accelerated luteinisation after } \\
\text { superovulation treatment }\end{array}$ \\
\hline Author(s) & $\begin{array}{l}\text { Hosotani, Marina; Ichii, Osamu; Nakamura, Teppei; Masum, Md A bdul; Otani, Y uki; Otsuka Kanazawa, Saori; Elewa, } \\
\text { Y aser H. A.; Kon, Y asuhiro }\end{array}$ \\
\hline Citation & $\begin{array}{l}\text { Reproduction, Fertility and Development, 31(4), 760-773 } \\
\text { https://doi.org/40.1071/RD18319 }\end{array}$ \\
\hline Issue Date & 2019-03 \\
\hline Doc URL & http://hdl.handle.net/2115/75893 \\
\hline Type & article (author version) \\
\hline File Information & Reproduction, Fertility and Development_31_4_760-773.pdf \\
\hline
\end{tabular}

Instructions for use 


\title{
MRL/MpJ mice produce more oocytes and exhibit impaired fertilisation and accelerated luteinisation after superovulation treatment
}

\author{
Marina Hosotani $^{\mathrm{A}}$, Osamu Ichii ${ }^{\mathrm{A}}$, Teppei Nakamura ${ }^{\mathrm{A}, \mathrm{B}}$, Md Abdul Masum $^{\mathrm{A}}$, Yuki Otani ${ }^{\mathrm{A}}$, Saori \\ Otsuka-Kanazawa ${ }^{\mathrm{A}}$, Yaser Hosny Ali Elewa ${ }^{\mathrm{A}}$ and Yasuhiro Kon ${ }^{\mathrm{A}, \mathrm{C}}$ \\ ${ }^{\mathrm{A}}$ Laboratory of Anatomy, Division of Basic Veterinary Sciences, Faculty of Veterinary \\ Medicine, Hokkaido University, Kita 18, Nishi 9, Kita-Ku, Sapporo, Hokkaido 060-0818, \\ Japan.
}

${ }^{B}$ Section of Biological Safety Research, Chitose Laboratory, Japan Food Research Laboratories, Bunkyo 2-3, Chitose, Hokkaido 066-0052, Japan.

CCorresponding author. Email: y-kon@vetmed.hokudai.ac.jp

MRL/MpJ mice exhibit distinct phenotypes in several biological processes, including wound healing.

Herein we report two unique phenotypes in the female reproductive system of MRL/MpJ mice that affect ovulation and luteinisation. We found that superovulation treatment resulted in the production of significantly more oocytes in MRL/MpJ than C57BL/6 mice (71.0 \pm 13.4 vs $26.8 \pm 2.8$ respectively). However, no exon mutations were detected in genes coding for female reproductive hormones or their receptors in MRL/MpJ mice. In addition, the fertilisation rate was lower for ovulated oocytes from MRL/MpJ than C57BL/6 mice, with most of the fertilised oocytes showing abnormal morphology, characterised by deformation and cytolysis. Histological tracing of luteinisation showed that MRL/MpJ mice formed corpora lutea within $36 \mathrm{~h}$ after ovulation, whereas C57BL/6 mice were still at the corpora haemorrhagica formation stage after $36 \mathrm{~h}$. The balance between the expression of matrix metalloproteinases and their tissue inhibitors shifted towards the former earlier after ovulation in MRL/MpJ than C57BL/6 mice. This result indicates a possible link between accelerated extracellular matrix remodelling in the ovulated or ruptured follicles and luteinisation in MRL/MpJ mice. Together, 
these findings reveal novel phenotypes in MRL/MpJ mice that provide novel insights into reproductive biology.

Additional keywords: Ovary, histology, in vitro fertilisation, extracellular matrix

M. Hosotani et al.

Unique ovulation and luteinisation in MRL/MpJ mice

We report two novel and unique phenotypes of MRL/MpJ mice in the female reproductive function.

Superovulation treatment resulted in the production of significantly more oocytes with lower quality, and the faster luteinisation of ovulated follicles in MRL/MpJ than C57BL/6 mice. Our results provide novel insights into the effects of artificial ovulation on oocytes and ovaries in mice.

\section{Introduction}

The Murphy Roths Large (MRL)/MpJ mouse strain was established by selective interbreeding of the C57BL/6 (0.3\%), C3H (12.1\%), AKR (12.6\%) and LG (75\%) strains (Heydemann 2012). MRL/MpJ is well known as a strain that exhibits a unique tissue repair response to various injuries (Heydemann 2012). For example, in MRL/MpJ mice, ear punches approximately $2 \mathrm{~mm}$ in diameter (Clark et al. 1998) or heart injuries induced with a cryoprobe (Leferovich et al. 2001) repair without scarring or fibrosis. In addition, after Caesarean delivery, uterine wound healing in MRL/MpJ mice showed histological, mitotic and functional differences compared with the C57BL/6 strain (Buhimschi et al. 2010). In the kidney, an organ that does not regenerate, fibrotic activity was lower and calcification was increased after acute injury in MRL/MpJ than C57BL/6 mice (Shiozuru et al. 2016).

The MRL/MpJ-Fas ${ }^{I p r / p r}$ strain, which bears the lymphoproliferation mutation (lpr) in the Fas cell surface death receptor (Fas) gene, exhibits severe autoimmune disease symptoms that are 
similar to human systemic lupus erythematosus (Santiago-Raber et al. 2004). Although MRL/MpJ mice have been used as healthy controls for MRL/MpJ-Fas ${ }^{l p r / p r}$ mice inpathological studies, they also show a propensity for autoimmune diseases (Heydemann 2012). Previously, we clarified the crucial contribution of the telomeric region of chromosome 1 in the pathogenesis of autoantibody production, splenomegaly and glomerulonephritis in MRL/MpJ mice (Ichii et al. 2008). We also identified several genetic loci associated with reproductive system phenotypes in this strain, such as the emergence of ovarian cysts (Kon et al. 2007), numerous ovarian mast cells (Nakamura et al. 2014), testicular oocytes (Otsuka et al. 2008) and spermatocyte apoptosis (Kon and Endoh 2000). Thus, MRL/MpJ mice show unique phenotypes not only with regard to tissue repair and autoimmune disease capacity, but also in the reproductive system.

Previously, we established a novel method to evaluate the pick-up efficiency of ovulated oocytes in mouse oviducts (Hosotani et al. 2018). Using this method, we found that MRL/MpJ mice subjected to hormonal superovulation produced a markedly larger number of cumulusoocyte complexes (COCs) than did C57BL/6 mice at 3 months of age (Hosotani et al. 2018). Surprisingly, the number of COCs in the ampulla of oviducts exceeded the number of 'ovulated oocytes' in the ovaries of MRL/MpJ mice, as determined histologically by counting the total number of ruptured follicles, corpora haemorrhagica and the follicular antrum containing no oocytes. These results suggest that the oocyte pick-up rate in MRL/MpJ mice was over 100\% (Hosotani et al. 2018). Therefore, we hypothesised that these unique ovarian phenotypes of MRL/MpJ mice may be due to a high sensitivity to superovulation treatment and/or faster luteinisation. Indeed, in support of the latter hypothesis, the sum of the histological number of ovulated oocytes and corpora lutea (CL) was comparable to the number of COCs in the ampulla of oviducts from MRL/MpJ mice (Hosotani et al. 2018). 
In the present study, to investigate these hypotheses and the functional implications of the phenotypes found in the MRL/MpJ strain, we evaluated the ovulation, luteinisation and fertilisation rates of ovulated oocytes in MRL/MpJ mice. The induction of ovulation or superovulation is an important technique in human and veterinary reproductive medicine. Our results provide novel insights into the effects of artificial ovulation on oocytes and ovaries in mice.

\section{Materials and methods}

\section{Animals}

Animal experimentation was approved by the Institutional Animal Care and Use Committee of the Graduate School of Veterinary Medicine, Hokkaido University (Approval no. 13-0031). Experimental animals were handled in accordance with the Guide for the Care and Use of Laboratory Animals, Graduate School of Veterinary Medicine, Hokkaido University (approved by the Association for Assessment and Accreditation of Laboratory Animal Care International). Male C57BL/6N, female C57BL/6N and female MRL/MpJ mice (3 months old) were obtained from Japan SLC. Mice were group housed in plastic cages at $18-26^{\circ} \mathrm{C}$ under a 12 -h light-dark cycle, and had free access to water and a commercial diet. All mice were killed by cutting the carotid artery or by cervical dislocation under deep anaesthesia using a mixture of medetomidine (0.3 mg kg-1), midazolam (4 $\left.\mathrm{mg} \mathrm{kg}^{-1}\right)$ and butorphanol (5 mg kg-1).

\section{IVF for the fertilisation rate assay}

IVF was conducted according to the manuals supplied by the Center for Animal Resources and Development, Kumamoto University (Takeo et al. 2008; Takeo and Nakagata 2010, 2011). 


\section{Collection of spermatozoa}

Spermatozoa were obtained from the cauda epididymides of a male C57BL/6N mouse, resuspended in a dish containing $100 \mu \mathrm{L}$ FERTIUP Mouse Sperm Preincubation Medium (KYUDO), covered with paraffin oil and incubated for $1 \mathrm{~h}$ at $37^{\circ} \mathrm{C}$ with $5 \% \mathrm{CO}_{2}$ in air.

\section{Collection of oocytes}

For superovulation treatment, pregnant mare’s serum gonadotrophin (PMSG; ASKA Animal Health) was injected into C57BL/6N $(n=5)$ and MRL/MpJ $(n=5)$ mice (200 $\mu \mathrm{L}$ of $37.5 \mathrm{IU}$ $\mathrm{mL}^{-1}$, i.p., per mouse). Forty-eight hours after PMSG injection, mice were injected with $200 \mu \mathrm{L}$ of $37.5 \mathrm{IU} \mathrm{mL} \mathrm{m}^{-1}$, i.p., human chorionic gonadotropin (hCG; ASKA Animal Health) per mouse. Mice were killed $24 \mathrm{~h}$ after hCG injection. Intact COCs were released from the excised oviduct into $200 \mu \mathrm{L}$ CARD MEDIUM (KYUDO), covered with paraffin oil and incubated for 30-60 min at $37^{\circ} \mathrm{C}$ with $5 \% \mathrm{CO}_{2}$ in air before insemination.

\section{Insemination}

After preincubation as described above, the sperm suspensions were added to a drop of CARD MEDIUM containing COCs and incubated for $24 \mathrm{~h}$ at $37^{\circ} \mathrm{C}$ with $5 \% \mathrm{CO}_{2}$ in air. The final concentration of motile spermatozoa in the fertilisation medium was 400-800 spermatozoa $\mu \mathrm{L}^{-1}$.

The embryos obtained were counted and classified into four categories according to morphological features: fertilised embryos, unfertilised embryos, abnormal cleavage embryos and dead embryos. The number of embryos in each category was determined under a stereoscopic microscope. The fertilisation rate was calculated as follows:

Fertilisation rate $(\%)=100 \times$ no. fertilised oocytes/(total no. fertilised and unfertilised oocytes) 
Oocyte counts under a natural oestrous cycle and after PMSG or hCG injection

The first group of female mice was mated with male mice in the evening. The next day, female mice $(n=5)$ with a vaginal plug were killed. The second group $(n=4)$ were injected with PMSG (200 $\mu \mathrm{L}$ of $37.5 \mathrm{IU} \mathrm{mL}^{-1}$, i.p., per mouse) and killed $24 \mathrm{~h}$ after injection. The third group $(n=4)$ were injected with hCG (200 $\mu \mathrm{L}$ of $37.5 \mathrm{IU} \mathrm{mL}^{-1}$, i.p., per mouse) at oestrus, which was determined by vaginal smear, and were killed $24 \mathrm{~h}$ after injection. COCs in the oviducts were extracted by oviductal perfusion with $0.01 \mathrm{M}$ phosphate-buffered saline and the number determined under a stereoscopic microscope.

\section{Next-generation exome sequencing}

Genomic DNA was isolated from the kidneys of C57BL/6N and MRL/MpJ mice with a DNeasy kit (Qiagen). Exome capture was performed using Sureselect XT Mouse All Exon kit (Agilent Technologies). Whole-exome sequencing was performed on a HiSeq2000 machine (Illumina). The mouse mm10 assembly downloaded from the University of California Santa Cruz (UCSC; http://genome.ucsc.edu/, accessed 13 Aug 2018) was used as the reference genome for sequence alignment. Reads were mapped using Burrows-Wheeler Aligner (BWA) version 0.5.9 (http://bio-bwa.sourceforge.net/, accessed 13 Aug 2018). Single nucleotide variants (SNVs) and small insertions/deletions were identified using SAMtools version 0.1.18 (http://samtools.sourceforge.net/, accessed 13 Aug 2018). We hypothesised that mutations in genes associated with female hormones or their receptors may contribute to the high sensitivity of MRL/MpJ mice to hCG. Therefore, we compared the exome sequences of the following genes between the two strains: inhibin alpha (Inha), inhibin beta-B (Inhbb), follicle stimulating hormone beta (Fshb), activin A receptor, type 1 (Acvr1), activin receptor IIA (Acvr2a), activin receptor IIB (Acvr2b), luteinising hormone beta ( $L h b)$, inhibin beta-A (Inhba), gonadotropin releasing hormone 1 (Gnrh1), luteinising hormone/choriogonadotrophin receptor (Lhcgr), 
follicle stimulating hormone receptor (Fshr), oestrogen receptor 1 (Esr1), oestrogen receptor 2 (Esr2) and progesterone receptor (Pgr).

\section{Histological analysis of luteinisation in superovulated mice}

Mice were either injected intraperitoneally with PMSG $\left(200 \mu \mathrm{L}\right.$ of $37.5 \mathrm{IU} \mathrm{mL}^{-\iota \mathrm{h}}$ per animal) followed $48 \mathrm{~h}$ later by hCG (200 $\mu \mathrm{L}$ of $37.5 \mathrm{IU} \mathrm{mL}^{-1}$ per animal) or had their ovaries removed. The hCG injection time point $48 \mathrm{~h}$ after the administration of PMSG was considered as $12 \mathrm{~h}$ before ovulation (or $-12 \mathrm{~h}$ postovulation (h.p.o.); $n=4$ ), with ovaries collected $72 \mathrm{~h}$ (12 h.p.o.; $n=6$ ), 78 h (18 h.p.o.; $n=4$ ) and 96 h (36 h.p.o.; $n=4$ ) later (Fig. 1 ). The ovaries were fixed with $4 \%$ paraformaldehyde at $4^{\circ} \mathrm{C}$ overnight, embedded in paraffin and cut into $10-\mu \mathrm{m}$ serial sections. Using serial hematoxylin-eosin (HE)-stained sections, the number of antral follicles, ruptured follicles, corpora haemorrhagica and CL was counted manually by histological observation, as described previously (Hosotani et al. 2018).

The ratio of the maximum to minimum diameter of oocytes contained in antral follicles was defined as the 'oocyte aspect ratio' and calculated on serial sections of superovulated ovaries at -12 h.p.o. Serial sections clearly showing the nucleolus were selected for this analysis. Four serial sections of ovaries were used and 13-15 oocytes from C57BL/6N mice and 40-61 oocytes from MRL/MpJ mice were analysed in each ovary to determine the oocyte aspect ratio. Reverse transcription and quantitative real-time polymerase chain reaction

Total RNA from ovaries of C57BL/6 and MRL/MpJ mice at 12 h.p.o. $(n=4)$ and 27 h.p.o. ( $n$ =4) was purified using TRIzol reagent (Life Technologies) according to the manufacturer's instructions. The purified total RNA (83.3 $n g \mathrm{~L}^{-1}$ ) was used as a template to synthesise cDNA using ReverTra Ace qPCR RT Master Mix (Toyobo). Quantitative polymerase chain reaction (qPCR) analysis was performed on the cDNA (20 ng $\left.\mu \mathrm{L}^{-1}\right)$ using THUNDERBIRD SYBR 
qPCR Mix (Toyobo) and the following gene-specific primers (5'-3'): matrix metalloproteinase 2 (Mmp2), ACGATGATGACCGGAAGTG (forward) and AATCGGAAGTTCTTGGTGTAGG (reverse; product size 157 bp); matrix metalloproteinase 9 (Mmp9), CATTCGCGTGGATAAGGAG (forward) and GAAACTCACACGCCAGAAGA (reverse; product size 112 bp); tissue-specific inhibitor of metalloproteinase 1 (Timp1), TCTGGCATCCTCTTGTTGCT (forward) and ACTCTTCACTGCGGTTCTGG (reverse; product size $292 \mathrm{bp}$ ); and $\beta$-actin (Actb; used as a housekeeping gene), TGTTACCAACTGGGACGACA (forward) and GGGGTGTTGAAGGTCTCAAA (reverse). The qPCR cycling conditions were $95^{\circ} \mathrm{C}$ for $1 \mathrm{~min}$, followed by 40 cycles of $95^{\circ} \mathrm{C}$ for $15 \mathrm{~s}$ and $60^{\circ} \mathrm{C}$ for $45 \mathrm{~s}$. Primers were obtained from Sigma-Aldrich. The concentration of the template RNA used in the reverse transcription reaction was $83.3 \mathrm{ng} \mu \mathrm{L}^{-1}$, whereas the concentration of cDNA used in the PCR reaction was $20.0 \mathrm{ng} \mu \mathrm{L}^{-1}$. Data were normalised against the expression level of $A c t b$ and analysed using the $\Delta \Delta \mathrm{C}_{\mathrm{t}}$ method.

\section{Statistical analysis}

Results are expressed as the mean \pm s.e.m. Non-parametric analyses were used to analyse the data. Data between two groups were compared using the Mann-Whitney $U$-test, with two-sided $P<0.05$ considered significant. The Kruskal-Wallis test was used to compare data among three or more groups. Multiple comparisons were performed using Scheffé's method when significant differences were observed overall $(P<0.05)$.

\section{Results}

Morphological features of embryos obtained after IVF

After IVF of oocytes obtained from C57BL/6 and MRL/MpJ mice, different categories of embryos (i.e. fertilised, unfertilised, abnormal and dead) were observed, as shown in Fig. $2 a-g$. 
Surprisingly, there were many dead embryos, characterised by oocyte deformation and cytolysis, were numerous in the MRL/MpJ group (Fig. 2g), but these were not observed in the C57BL/6 group.

Histological ovary sections were obtained from mice at -12 h.p.o., a time point when antral follicles are considered to be maturing for ovulation. In the antral follicles of MRL/MpJ mice, elongated or compacted oocytes were frequently observed, whereas regular round-shaped oocytes were found in the antral follicles of the C57BL/6 mice (Fig. 2h, i). As shown in Fig. $2 j$, the oocyte aspect ratio was significantly higher in MRL/MpJ than C57BL/6 mice (1.40 \pm 0.04 vs $1.20 \pm 0.02$ respectively), indicating an altered oocyte morphology in the antral follicles of MRL/MpJ mice. $b$

Number of embryos obtained after IVF and the fertilisation rate in MRL/MpJ than C57BL/6 mice

After superovulation treatment, MRL/MpJ mice produced 71.0 \pm 13.4 COCs, whereas C57BL/6 mice produced $26.8 \pm 2.8$ COCs (Fig. 3a). In C57BL/6 mice, the number of fertilised, unfertilised, abnormal and dead embryos was $12.8 \pm 1.6(47.7 \pm 2.5 \%$ of the total collected embryos), $1.2 \pm 0.4$ (4.9 $\pm 1.5 \%), 12.8 \pm 1.6(47.4 \pm 2.0 \%)$ and 0 (0\%) respectively. In MRL/MpJ mice, these number of fertilised, unfertilised, abnormal and dead embryos was $11.6 \pm$ 4.6 (16.6 $\pm 4.4 \%), 9.2 \pm 2.2(14.7 \pm 5.1 \%), 17.2 \pm 3.2(24.7 \pm 2.3 \%)$ and $33.0 \pm 9.2(43.9 \pm$ 7.1\%), respectively. The number of unfertilised and dead embryos was significantly larger in MRL/MpJ than C57BL/6 mice. Furthermore, the fertilisation rate was significantly lower in MRL/MpJ than C57BL/6 mice (52.3 $\pm 11.9 \%$ vs $90.7 \pm 2.8 \%$ respectively; Fig. $3 b$ ).

Number of COCs obtained under a natural oestrus cycle or after PMSG treatment

Under a natural oestrous cycle without superovulation treatment, C57BL/6 and MRL/MpJ mice ovulated $10.3 \pm 0.5$ and $12.0 \pm 0.9$ COCs respectively, with no significant difference 
between the two strains (Fig. 4a). Because in non-equine species PMSG stimulates not only follicular development, but also ovulation (Practice Committee of the American Society for Reproductive Medicine Birmingham Alabama 2008), we also counted the number of ovulated COCs following injection of PMSG. After a single PMSG injection, C57BL/6 and MRL/MpJ mice ovulated $9.5 \pm 2.7$ and $9.5 \pm 2.5$ COCs respectively, which did not differ significantly (Fig. $4 b$ ). In contrast, the number of ovulated COCs after hCG treatment was significantly higher in MRL/MpJ than C57BL/6 mice (16.8 \pm 4.2 vs $2.5 \pm 2.5$ respectively; Fig. $4 c)$.

\section{Comparative sequence analysis of ovulation-related genes in C57BL/6 and MRL/MpJ mice}

We hypothesised that mutations in genes associated with female hormones or their receptors may contribute to the high sensitivity of MRL/MpJ mice to hCG. Therefore, we compared the exome sequences of Inha, Inhbb, Fshb, Acvr1, Acvr2a, Acvr2b, Lhb, Inhba, Gnrh1, Lhcgr, Fshr, Esr1, Esr2 and Pgr genes between the two strains (Table 1). Genetic variants were detected in the following genes in MRL/MpJ mice: Acvr1 (one synonymous exon variant and six intron variants), Acvr2b (seven synonymous exon and 15 intron variants), Gnrh1 (one intron variant and one variant in the 3' untranslated region (UTR)), Lhcgr (one synonymous exon, 12 intron and two upstream region variants) and Esr1 (two synonymous exon variants and 12 intron variants). In addition to nine intron variants and five synonymous exon variants, Pgr in MRL/MpJ mice had two non-synonymous exon variants. The first one exon variant was a missense variant in position 118 in the DNA sequence (TCG) causing the serine to be replaced with a threonine, yielding ACG in the DNA sequence (variant ID: rs16808507). The second exon variant in Pgr was also a missense variant, in position 252 in the DNA sequence (GGA), causing the glycine to be replaced with a glutamic acid, yielding GAA (variant ID:

rs16808511). Representatively, mice of the AKR/J and NZB/BINJ strains also have these two non-synonymous variants in Pgr (Mouse Phenome Database; https://phenome.jax.org/, data 
accessed 13 Apr 2018). The number of embryos produced from the AKR/J and NZB/BINJ strains after superovulation treatment has been reported to be approximately 20 and 10 respectively (Spearow 1988; Yokoyama and Hioki 1990), indicating that it is unlikely that these variants cause the ovulation of high number of embryos in mice.

No variants were detected in the Inha, Inhbb, Acvr2a, Fshb, Lhb, Inhba, Fshr and Esr2 genes. Thus, no coding region mutations affecting protein structure were identified in the genes examined.

\section{Folliculogenesis and luteinisation after superovulation treatment}

We examined ovarian histology after superovulation (Fig. $5 a-j$ ). At -12 h.p.o., just before ovulation, numerous antral follicles were observed and CL occupied the remaining space of the ovaries in both C57BL/6 and MRL/MpJ mice (Fig. 5a,f). At 12 h.p.o., ruptured follicles and corpora haemorrhagica were detected, and several antral follicles and CL were observed in both strains (Fig. 5b, g). At 18 and 36 h.p.o., some corpora haemorrhagica remained, and several CL were observed in the ovaries of C57BL/6 mice (Fig. 5c, d). In contrast, in MRL/MpJ mice, the number of CL in the ovaries increased at 18 h.p.o. (Fig. 5h) compared with 12 h.p.o. (Fig. $5 g$ ). At 36 h.p.o., numerous CL occupied almost the whole ovary in MRL/MpJ mice (Fig. 5i). The CL in both strains consisted of fibroblasts, vascular endothelial cells and granulosa and theca lutein cells containing vacuoles (Fig. 5e, j).

Next, we counted the number of antral follicles, ruptured follicles, corpora haemorrhagica and $\mathrm{CL}$ after superovulation in C57BL/6 and MRL/MpJ mice (Fig. $6 a, b$ ). In C57BL/6 mice, the number of antral follicles was significantly greater at -12 than at 12,18 and 36 h.p.o. (15 \pm 1 vs $5.1 \pm 0.9,5.0 \pm 0.9$ and $1.8 \pm 0.8$ respectively; $P<0.05$ ). The number of ruptured follicles was significantly greater at 12 h.p.o. $(10.0 \pm 1.7)$ than at other time points $(0.3 \pm 0.3,0.8 \pm 0.5$ and 
$0.3 \pm 0.3$ at $-12,18$ and 36 h.p.o. respectively; $P<0.05$ ) and the number of corpora haemorrhagica were significantly greater at 18 and 36 h.p.o. $(14.0 \pm 2.7$ and $9.0 \pm 1.5$ respectively) than at -12 and 12 h.p.o. ( $0.3 \pm 0.3$ and $0.7 \pm 0.4$ respectively). However, the number of CL did not change significantly throughout the observation period (8.5 $\pm 1.6,13.4 \pm$ $1.8,10.8 \pm 2.9$ and $9.5 \pm 2.3$ at $-12,12,18$ and 36 h.p.o. respectively).

Similar to C57BL/6 mice, the number of antral follicles in the MRL/MpJ strain was significantly greater at -12 h.p.o. (66.0 \pm 4.9$)$ than at other time points, and significantly greater at 12 and 18 than at 36 h.p.o. $(22.0 \pm 2.3$ and $26.5 \pm 1.9$ vs $4.5 \pm 2.5$ respectively; $P<0.05)$. The number of ruptured follicles was significantly greater at 12 h.p.o. $(21.0 \pm 0.9)$ than at other time points, and significantly greater at 18 than at -12 and 36 h.p.o. (9.5 \pm 1.8 vs $0 \pm 0$ and $0 \pm 0$ respectively; $P<0.05$ ). However, unlike C57BL/6 mice, in MRL/MpJ mice there number of CL was significantly greater at 36 than at 12 h.p.o. ( $37.3 \pm 6.1$ vs $16.7 \pm 1.2$ respectively; $P<0.05$ ).

The percentage of antral follicles, ruptured follicles, corpora haemorrhagica and CL relative to the total number of observed structures is shown in Fig. $6 c$, $d$. At -12 h.p.o., percentages were similar in the $\mathrm{MRL} / \mathrm{MpJ}$ and C57BL/6 groups. At 12 h.p.o., the ovaries of MRL/MpJ mice had a significantly higher percentage of corpora haemorrhagica and a lower percentage of CL than in C57BL/6 mice. At 18 h.p.o., the percentage of antral follicles and ruptured follicles was significantly higher, whereas the percentage of corpora haemorrhagica was lower in ovaries of MRL/MpJ than C57BL/6 mice. Importantly, at 36 h.p.o., the percentage of corpora haemorrhagica was significantly lower and the percentage of CL was significantly higher in MRL/MpJ than C57BL/6 mice $(P<0.05)$. These data indicate differences in ovarian phenotypes between C57BL/6 and MRL/MpJ mice; in particular, there is an accelerated luteinisation in the latter strain. 
Expression of MMPs and TIMPs in ovaries during luteinisation

MMPs and TIMPs play a key role in the breakdown of extracellular matrix (ECM) for luteinisation (Woessner 1991; Stocco et al. 2007). Among the MMP family of proteins, Mmp2 and Mmp9 appear to be important for luteinisation (Stocco et al. 2007). Our findings (Fig. 6d) suggest that ovaries of MRL/MpJ mice are forming CL most actively between 18 and 36 h.p.o. Therefore, we examined the expression of Mmp2, Mmp9 and Timp1 in ovaries of C57BL/6 and MRL/MpJ mice at 12 h.p.o. (before luteinisation) and at 27 h.p.o. (during luteinisation; Fig. 7). The expression of Mmp2 and Mmp9 did not change in either strain between 12 and 27 h.p.o., whereas Timp1 expression was significantly lower at 27 than at 12 h.p.o. in MRL/MpJ mice (Fig. 7a). Mmp9 expression at 12 h.p.o. was significantly lower in MRL/MpJ than C57BL/6 mice $(P<0.05)$. The ratio of $M m p 2$ and Mmp9 expression relative to that of Timp1 increased significantly at 27 h.p.o. compared with 12 h.p.o. in MRL/MpJ mice (Fig. 7b).

In addition, we compared the exome sequences of Mmp2, Mmp9 and Timp1 (Table 2). No variants were detected in Timp1. Mmp2 in MRL/MpJ mice had 18 synonymous exon variants, 47 intron variants and one variant in the 5'UTR. Mmp9 in MRL/MpJ mice had one nonsynonymous exon variant, which was a missense variant in position 639 in the DNA sequence (CTC) in which leucine was replaced with proline, yielding CCC in the DNA sequence (variant ID: rs13475086). AKR/J and BALB/cJ mice also harbour this non-synonymous variant in Mmp9 (Mouse Phenome Database; https://phenome.jax.org/, data accessed 13 Apr 2018). These strains of mice exhibit slower healing than MRL/MpJ mice (Li et al. 2001), indicating that it is unlikely that this variant causes the faster luteinisation related to the faster healing in $\mathrm{MRL} / \mathrm{MpJ}$ mice. 


\section{Discussion}

Consistent with our previous findings (Hosotani et al. 2018) and other reports (Yokoyama and Hioki 1990), in this study MRL/MpJ mice ovulated significantly more COCs than did C57BL/6 mice after superovulation treatment. MRL/MpJ mice generated approximately 70 oocytes after the injection of PMSG and hCG, and approximately 10 oocytes in the normal oestrous cycle. These results indicate that the MRL/MpJ strain has a higher sensitivity to these gonadotrophin treatments than does the C57BL/6 strain. In equines, PMSG is known as the equine chorionic gonadotrophin and shows only LH-like activity (Practice Committee of the American Society for Reproductive Medicine Birmingham Alabama 2008). However, in nonequine species, PMSG shows both FSH and LH activity, and thus stimulates not only folliculogenesis, but also ovulation and luteinisation (Practice Committee of the American Society for Reproductive Medicine Birmingham Alabama 2008). A previous study discussed the possibility that ovulated oocytes induced by PMSG treatment remained in the oviducts until subsequent ovulation following injection of hCG (Yokoyama and Hioki 1990). However, in the present study the number of ovulated COCs following PMSG treatment was almost equal between the MRL/MpJ and C57BL/6 strains, and comparable to that of COCs under the natural oestrous cycle. This is consistent with the findings of another study that compared the number of ovulated oocytes after PMSG injection with that ovulated in normal oestrus (Kaufman and Whittingham 1972). Interestingly, MRL/MpJ mice produced more COCs than did C57BL/6 mice after a single injection of hCG. However, the total number of COCs generated following injection of either PMSG or hCG alone did not reach the number generated after sequential injections of PMSG and hCG. Therefore, both hCG and sequential injections of PMSG and hCG have stronger effects on ovulation in MRL/MpJ than C57BL/6 mice. Based on these findings, we hypothesised that mutations in genes associated with female hormones and their 
receptors contributed to the high sensitivity to hCG observed in the MRL/MpJ strain. However, comparison of the exon sequences of several such genes (Inha, Inhbb, Fshb, Acvr1, Acvr2a, Acvr2b, Lhb, Inhba, Gnrh, Lhcgr and Fshr) between the C57BL/6 and MRL/MpJ strains found no coding region variants predicted to affect protein structure and function. Therefore, the superovulation-related phenotype in MRL/MpJ mice may be related to an altered expression of these genes in the ovary and/or in other organs associated with the hypothalamic-pituitarygonadal axis, which could arise due to genetic variation in sequences outside of coding regions, such as in gene promoters.

Approximately 44\% of embryos developed from ovulated oocytes in MRL/MpJ mice were dead, and the fertilisation rate was significantly lower for the MRL/MpJ than C57BL/6 strain. These results indicate the low quality of ovulated oocytes in MRL/MpJ mice. Various factors, such as genes, hormone levels, chemical interactions and environment and physical conditions, affect oocyte quality (Mermillod et al. 2008; Revelli et al. 2009; Sirotkin 2010; Carpintero et al. 2014). Importantly, previous studies reported that the percentage of cells undergoing apoptosis in cumulus cells increased in oocytes within follicles subjected to hydrostatic pressure (Rashidi et al. 2014). Our histological observations revealed a more elongated oocyte morphology in $\mathrm{MRL} / \mathrm{MpJ}$ than C57BL/6 mice. It is not clear whether this morphological change is due to factors intrinsic to oocytes or whether it is influenced by the microenvironment, such as by pressure from the large number of developing follicles in MRL/MpJ mice. Because ovaries in MRL/MpJ mice contain a larger number of follicles than ovaries in C57BL/6 mice, it is possible that the poorer oocyte quality in MRL/MpJ mice results from exposure to high pressure. We did not observe the morphological abnormality in embryos in vitro. Furthermore, the in vitro fertilisation rate of human ovoid embryos is not affected, but delayed preimplantation development is seen (Ebner et al. 2008). There are no reports regarding how an ovoid shape of 
oocytes in ovarian sections can affect the fertilisation rate and oocyte quality. However, the data suggest the possibility that an excessive number of follicles in an ovary can affect the oocyte quality in multifetal animals such as mice.

The folliculogenesis pattern was similar in MRL/MpJ and C57BL/6 mice before ovulation and the injection of hCG, with antral follicles accounting for most follicles in the ovary. After ovulation, MRL/MpJ mice formed CL within $36 \mathrm{~h}$, whereas corpora haemorrhagica were numerous in C57BL/6 mice even after $36 \mathrm{~h}$. These results indicate that the differentiation of ovulated follicles to CL occurs faster in MRL/MpJ than C57BL/6 mice. In addition, the higher percentage of ruptured follicles at 18 h.p.o. in MRL/MpJ than C57BL/6 mice indicates that ovulation from matured follicles continues for a longer period in MRL/MpJ than C57BL/6 mice, which may be due to the high sensitivity of the former strain to artificial ovulation.

In a previous study (Hosotani et al. 2018), we considered that the accelerated luteinisation in MRL/MpJ mice would be associated with the enhanced healing ability in this strain. Several possible explanations for the enhanced healing capacity of MRL/MpJ mice have been proposed, including cell cycle and proliferative features, increased stem cell quantity and/or quality and enhanced immune response (Heydemann 2012). In particular, changes in the ECM regulated by MMPs appeared to be crucial for the healing capacity of the MRL/MpJ strain (Heydemann 2012). ECM remodelling is cooperatively and tightly regulated by interactions between proteases and their inhibitors, such as MMPs and TIMPs respectively (Woessner 1991). For example, it was proposed that neutrophils and macrophages within wounds secrete significantly higher amounts of active MMP-2 and MMP-9 and lower amounts of TIMPs in MRL/MpJ than C57BL/6 mice (Gourevitch et al. 2003; Heydemann 2012). Importantly, in the CL, a transient endocrine gland, marked morphological changes are found upon the differentiation of luteal cells, and this process also involves changes in the ECM that enable cell migration and 
neovascularisation in the newly formed CL (Davis and Rueda 2002; Stocco et al. 2007). Within the MMP family of proteins, MMP-2 and MMP-9 appear to be important for luteinisation (Stocco et al. 2007). The ratio of active MMPs to TIMPs may be important in maintaining an ECM microenvironment conducive to the differentiation of follicle-derived cells into luteal cells (Smith et al. 1999). Our results showed that the ratio of Mmp2 and Mmp9 to Timp1 was elevated earlier in MRL/MpJ than C57BL/6 mice, resulting in the MMP-TIMP balance shifting towards MMP shortly after ovulation in MRL/MpJ mice. This suggests that accelerated ECM remodelling, as observed in wound healing, also occurs in the ovulated and ruptured follicles in MRL/MpJ mice, leading to quick luteinisation. In addition, oocyte development during nest breakdown and folliculogenesis is accelerated in neonatal MRL/MpJ mice (Yamashita et al. 2015), and this strain has a high frequency of ovarian cysts at older ages (Kon et al. 2007; Lee et al. 2011). Together, these results indicate that the MRL/MpJ mice have unique phenotypes associated with the female reproductive system throughout life.

In conclusion, the matured MRL/MpJ strain has unique phenotypes in female reproductive function, such as high sensitivity to gonadotrophin treatment and a faster process of luteinisation; these characteristics can contribute to the study of the mechanism of follicle remodelling and female reproductive function.

\section{Conflicts of interest}

The authors declare no conflicts of interest.

\section{Acknowledgements}

This work was supported, in part, by the Hokkaido University Tenure Track Program (Y. H. A. Elewa) and the Program for Leading Graduate Schools (Hokkaido University) from the Japanese Ministry of Education, Culture, Sports, Science and Technology (M. Hosotani). The research described in this paper 
was presented, in part, at the 159th Japanese Association of Veterinary Anatomists, 6-8 September 2016, Kanagawa, Japan, at the 160th Japanese Association of Veterinary Anatomists, 15 September 2017, Kagoshima, Japan, and at the 6th Congress of Asian Association of Veterinary Anatomists, 15-16 October 2017, Kuching, Malaysia.

\section{References}

Buhimschi, C. S., Zhao, G., Sora, N., Madri, J. A., Buhimschi, I. A., Allsworth, J., Stevens, E., Macones, G., Buhimschi, C., and Weiner, C. (2010). Myometrial wound healing post-cesarean delivery in the MRL/MpJ mouse model of uterine scarring. Am. J. Pathol. 177, 197-207 doi:10.2353/ajpath.2010.091209.

Carpintero, N. L., Suárez, O. A., Mangas, C. C., Varea, C. G., and Rioja, R. G. (2014). Follicular steroid hormones as markers of oocyte quality and oocyte development potential. J. Hum. Reprod. Sci. 7, 187193 doi:10.4103/0974-1208.142479.

Clark, L. D., Clark, R. K., and Heber-Katz, E. (1998). A new murine model for mammalian wound repair and regeneration. Clin. Immunol. Immunopathol. 88, 35-45 doi:10.1006/clin.1998.4519.

Davis, J. S., and Rueda, B. R. (2002). The corpus luteum: an ovarian structure with maternal instincts and suicidal tendencies. Front. Biosci. 7, 1949-1978 doi:10.2741/davis1.

Ebner, T., Shebl, O., Moser, M., Sommergruber, M., and Tews, G. (2008). Developmental fate of ovoid oocytes. Hum. Reprod. 23, 62-66 doi:10.1093/humrep/dem280.

Gourevitch, D., Clark, L., Chen, P., Seitz, A., Samulewicz, S. J., and Heber-Katz, E. (2003). Matrix metalloproteinase activity correlates with blastema formation in the regenerating MRL mouse ear hole model. Dev. Dyn. 226, 377-387 doi:10.1002/dvdy.10243. 
Heydemann, A. (2012). The super super-healing MRL mouse strain. Front. Biol. (Beijing) 7, 522-538 doi:10.1007/s11515-012-1192-4.

Hosotani, M., Ichii, O., Nakamura, T., Kanazawa, S. O., Elewa, Y. H. A., and Kon, Y. (2018).

Autoimmune abnormality affects ovulation and oocyte-pick-up in MRL/MpJ-Fas ${ }^{l p r / p r}$ mice. Lupus 27, 82-94 doi:10.1177/0961203317711772.

Ichii, O., Konno, A., Sasaki, N., Endoh, D., Hashimoto, Y., and Kon, Y. (2008). Autoimmune glomerulonephritis induced in congenic mouse strain carrying telomeric region of chromosome 1 derived from MRL/MpJ. Histol. Histopathol. 23, 411-422 doi:10.14670/HH-23.411.

Kaufman, M. H., and Whittingham, D. G. (1972). Viability of mouse oocytes ovulated within 14 hours of an injection of pregnant mares' serum gonadotrophin. J. Reprod. Fertil. 28, 465-468 doi:10.1530/jrf.0.0280465.

Kon, Y., and Endoh, D. (2000). Morphological study of metaphase-specific apoptosis in MRL mouse testis. Anat. Histol. Embryol. 29, 313-319 doi:10.1046/j.1439-0264.2000.00279.x.

Kon, Y., Konno, A., Hashimoto, Y., and Endoh, D. (2007). Ovarian cysts in MRL/MpJ mice originate from rete ovarii. Anat. Histol. Embryol. 36, 172-178 doi:10.1111/j.1439-0264.2006.00728.x.

Lee, S.-H., Ichii, O., Otsuka, S., Yaser Hosney, E., Namiki, Y., Hashimoto, Y., and Kon, Y. (2011). Ovarian cysts in MRL/MpJ mice are derived from the extraovarian rete: a developmental study. $J$. Anat. 219, 743-755 doi:10.1111/j.1469-7580.2011.01431.x.

Leferovich, J. M., Bedelbaeva, K., Samulewicz, S., Zhang, X. M., Zwas, D., Lankford, E. B., and HeberKatz, E. (2001). Heart regeneration in adult MRL mice. Proc. Natl Acad. Sci. USA 98, 9830-9835 doi:10.1073/pnas.181329398. 
Li, X., Gu, W., Masinde, G., Hamilton-Ulland, M., Xu, S., Mohan, S., and Baylink, D. J. (2001). Genetic control of the rate of wound healing in mice. Heredity 86, 668-674 doi:10.1046/j.1365-

$\underline{2540.2001 .00879 . x}$.

Mermillod, P., Dalbis-Tran, R., Uzbekova, S., Thlie, A., Traverso, J.-M., Perreau, C., Papillier, P., and Monget, P. (2008). Factors affecting oocyte quality: who is driving the follicle? Reprod. Domest. Anim. 43, 393-400 doi:10.1111/j.1439-0531.2008.01190.x.

Nakamura, T., Sakata, Y., Otsuka-Kanazawa, S., Ichii, O., Chihara, M., Nagasaki, K., Namiki, Y., and Kon, Y. (2014). Genomic analysis of the appearance of ovarian mast cells in neonatal MRL/MpJ mice. PLoS One 9, e100617. doi:10.1371/journal.pone.0100617

Otsuka, S., Konno, A., Hashimoto, Y., Sasaki, N., Endoh, D., and Kon, Y. (2008). Oocytes in newborn MRL mouse testes. Biol. Reprod. 79, 9-16 doi:10.1095/biolreprod.107.064519.

Practice Committee of the American Society for Reproductive Medicine, Birmingham, Alabama. (2008). Gonadotropin preparations: past, present, and future perspectives. Fertil. Steril. 90(Suppl.), S13-S20 doi:10.1016/j.fertnstert.2008.08.031.

Rashidi, Z., Azadbakht, M., Amini, A., and Karimi, I. (2014). Hydrostatic pressure affects in vitro maturation of oocytes and follicles and increases granulosa cell death. Cell J. 15, 282-293.

Revelli, A., Delle Piane, L., Casano, S., Molinari, E., Massobrio, M., and Rinaudo, P. (2009). Follicular fluid content and oocyte quality: from single biochemical markers to metabolomics. Reprod. Biol. Endocrinol. 7, 40 doi:10.1186/1477-7827-7-40.

Santiago-Raber M.-L., Laporte C., Reininger L., and Izui S. (2004). Genetic basis of murine lupus. Autoimmun. Rev. 3, 33-39. doi:10.1016/S1568-9972(03)00062-4 
Shiozuru, D., Ichii, O., Kimura, J., Nakamura, T., Elewa, Y. H. A., Otsuka-Kanazawa, S., and Kon, Y.

(2016). MRL/MpJ mice show unique pathological features after experimental kidney injury. Histol.

Histopathol. 31, 189-204.

Sirotkin, A. V. (2010). Effect of two types of stress (heat shock/high temperature and malnutrition/serum deprivation) on porcine ovarian cell functions and their response to hormones. J. Exp. Biol. 213, 21252130 doi:10.1242/jeb.040626.

Smith, M. F., McIntush, E. W., Ricke, W. A., Kojima, F. N., and Smith, G. W. (1999). Regulation of ovarian extracellular matrix remodelling by metalloproteinases and their tissue inhibitors: effects on follicular development, ovulation and luteal function. J. Reprod. Fertil. Suppl. 54, 367-381.

Spearow, J. L. (1988). Major genes control hormone-induced ovulation rate in mice. J. Reprod. Fertil. 82, 787-797 doi:10.1530/jrf.0.0820787.

Stocco, C., Telleria, C., and Gibori, G. (2007). The molecular control of corpus luteum formation, function, and regression. Endocr. Rev. 28, 117-149 doi:10.1210/er.2006-0022.

Takeo, T., and Nakagata, N. (2010). Combination medium of cryoprotective agents containing Lglutamine and methyl- $\beta$-cyclodextrin in a preincubation medium yields a high fertilization rate for cryopreserved C57BL/6J mouse sperm. Lab. Anim. 44, 132-137 doi:10.1258/la.2009.009074.

Takeo, T., and Nakagata, N. (2011). Reduced glutathione enhances fertility of frozen/thawed C57BL/6 mouse sperm after exposure to methyl-beta-cyclodextrin. Biol. Reprod. 85, 1066-1072 doi:10.1095/biolreprod.111.092536.

Takeo, T., Hoshii, T., Kondo, Y., Toyodome, H., Arima, H., Yamamura, K., Irie, T., and Nakagata, N. (2008). Methyl-beta-cyclodextrin improves fertilizing ability of C57BL/6 mouse sperm after freezing and thawing by facilitating cholesterol efflux from the cells. Biol. Reprod. 78, 546-551 doi:10.1095/biolreprod.107.065359. 
Woessner, J. F. (1991). Matrix metalloproteinases and their inhibitors in connective tissue remodeling.

FASEB J. 5, 2145-2154 doi:10.1096/fasebj.5.8.1850705.

Yamashita, Y., Nakamura, T., Otsuka-Kanazawa, S., Ichii, O., and Kon, Y. (2015). Morphological characteristics observed during early follicular development in perinatal MRL/MpJ mice. Jpn. J. Vet. Res. 63, 25-36 doi:10.14943/jjvr.63.1.25.

Yokoyama, M., and Hioki, K. (1990). The copulation rate and the embryo recovery rate following induced superovulation in various strains of mice. J. Mamm. Ova Res. 7, 89-94 doi:10.14893/jmor1984.7.89.

Fig. 1. The superovulation treatment protocol used in the present study. Mice were injected with pregnant mare’s serum gonadotrophin (PMSG) intraperitoneally; $48 \mathrm{~h}$ after PMSG injection, defined as $12 \mathrm{~h}$ postovulation (h.p.o.), mice were injected intraperitoneally with human chorionic gonadotrophin (hCG) or had their ovaries removed. Ovaries were collected 24 h (12 h.p.o.), 30 h (18 h.p.o.), 39 h (27 h.p.o.) and 48 h (36 h.p.o.) after hCG injection.

Fig. 2. Morphological observations of embryos after IVF of oocytes obtained from superovulated C57BL/6 $(a, c, e)$ and MRL/MpJ ( $b, d, f)$ mice. $(a, b)$ Fertilised embryos that have two cells of the same size. $(c, d)$ Unfertilised embryos. $(e, f)$ Abnormal cleavage in embryos, which have either three or more cells or two cells of different sizes. ( $g$ ) Dead embryos derived from MRL/MpJ mice that have a large cytoplasm and condensed cells. $(h, i)$ Morphological differences between oocytes contained in antral follicles at -12 h.p.o. in C57BL/6 and MRL/MpJ mice. Scale bars $=50 \mu \mathrm{m}$. $(j)$ The oocyte aspect ratio (maximum diameter/minimum diameter) in C57BL/6 mice ( $n=4$; 13-15 oocytes analysed in each ovary) and MRL/MpJ mice ( $n=4$; 40-61 oocytes analysed in each ovary). Data are the mean \pm s.e.m. ${ }^{*} P<0.05$ (Mann-Whitney $U$-test). 
Fig. 3. Results of the fertilisation assay in embryos obtained from superovulated C57BL/6 and MRL/MpJ mice. (a) Number of different types of embryos generated per mouse through IVF. Data are the mean \pm s.e.m. ( $n=5$ in each strain). ${ }^{*} P<0.05$ (Mann-Whitney $U$-test). ${ }^{\dagger} P<0.05$ compared with the same embryo type in C57BL/6 mice (Mann-Whitney $U$-test). (b) Fertilisation rate calculated from the number of fertilised and unfertilised embryos shown in $(a)$. Data are the mean \pm s.e.m. $(n=5$ in each strain). ${ }^{*} P<0.05$ (Mann-Whitney $U$-test).

Fig. 4. Number of cumulus-oocyte complexes (COCs) produced ( $a$ ) under a natural oestrous cycle and after injection of (b) pregnant mare’s serum gonadotrophin (PMSG) or (c) human chorionic gonadotrophin (hCG). Data are the mean \pm s.e.m. ( $n=5$ in each strain for $(a) ; n=4$ in each strain for $(b)$ and $(c))$. There were no significant differences in the number of COCs ovulated between C57BL/6 and MRL/MpJ mice under a natural oestrous cycle or after injection of PMSG. ${ }^{*} P<0.05$ (Mann-Whitney $U$ test).

Fig. 5. Ovarian histology before and after superovulation in C57BL/6 and MRL/MpJ mice. CL, corpus luteum; h.p.o., h postovulation. The squares indicated in $(d)$ and $(i)$ are magnified in $(e)$ and $(j)$ respectively, with insets showing lutein cells containing vacuoles. Arrows indicate antral follicles, arrowheads indicate ruptured follicles, daggers indicate corpora haemorrhagica and asterisks indicate corpora lutea. Scale bars $=300 \mu \mathrm{m}(a-d, f-i) ; 50 \mu \mathrm{m}(e, j)$.

Fig. 6. $(a, b)$ Number and $(c, d)$ percentage of ovarian follicle-related structures in superovulated C57BL/6 $(a, c)$ and MRL/MpJ $(b, d)$ mice. Data are the mean \pm s.e.m. of ovaries from four mice in each group at -12, 18 and 36 h postovulation (h.p.o.) and six mice in each group at 18 h.p.o. Asterisks indicate significant differences compared with the other three time points within the same strain are shown. Significant differences $-12,12$ and 36 h.p.o. within the same strain are indicated as ' -12 ', ' 12 ' and ' 36 ' respectively ( $P<0.05$, Kruskal-Wallis test followed by Scheffé's test). In $(d)$, the daggers indicate 
significant differences in the same structure compared with the C57BL/6 strain $(P<0.05$, Mann-Whitney $U$-test).

Fig. 7. (a) Expression of matrix metalloproteinase 2 (Mmp2), matrix metalloproteinase 9 (Mmp9) and tissue-specific inhibitor of metalloproteinase 1 (Timp1) mRNA during luteinisation in ovaries of superovulated C57BL/6 and MRL/MpJ mice and (b) the ratio of matrix metalloproteinase (MMP) mRNA to Timp1 expression, as determined by quantitative real-time polymerase chain reaction at 12 and $27 \mathrm{~h}$ postovulation (h.p.o.). Data are the mean \pm s.e.m. ( $n=4$ for each strain at each time point). ${ }^{*} P<0.05$ (Mann-Whitney $U$-test). 
Table 1. Polymorphisms in ovulation-related genes detected between C57BL/6 and MRL/MpJ strains using next-generation sequencing

chr, chromosome; SNV, single nucleotide variant; Acvr1, activin A, type1; Acv2b, activin receptor IIB; Gnrh1, gonadotrophin-releasing hormone 1; Lhcgr, luteinising hormone/choriogonadotrophin receptor; Pgr, progesterone receptor; Esr1, oestrogen receptor 1; UTR, untranslated region

\begin{tabular}{|c|c|c|c|c|c|c|c|c|}
\hline \multirow[t]{2}{*}{ Gene } & \multirow{2}{*}{$\begin{array}{l}\text { Chr } \\
\text { no. }\end{array}$} & \multicolumn{2}{|c|}{ Location (bp) } & \multicolumn{2}{|c|}{ Strains } & \multirow[t]{2}{*}{ Region } & \multirow[t]{2}{*}{ Change } & \multirow[t]{2}{*}{ Variant ID } \\
\hline & & Start & End & C57BL/6 & MRL/MpJ & & & \\
\hline \multirow[t]{7}{*}{ Acvr1 } & chr02 & 58448495 & 58448495 & A & G & Intron & - & rs214065797 \\
\hline & & 58458835 & 58458835 & G & $\mathrm{T}$ & Intron & - & rs230650639 \\
\hline & & 58458868 & 58458868 & $\mathrm{~T}$ & $\mathrm{C}$ & Intron & - & rs246215171 \\
\hline & & 58463020 & 58463020 & $\mathrm{~T}$ & $\mathrm{C}$ & Exon & Synonymous SNV & rs33549343 \\
\hline & & 58463229 & 58463229 & G & A & Intron & - & rs228629097 \\
\hline & & 58477571 & 58477571 & A & G & Intron & - & rs27909412 \\
\hline & & 58500669 & 58500669 & $\mathrm{C}$ & A & Intron & - & rs261538744 \\
\hline \multirow[t]{10}{*}{$A c v r 2 b$} & chr09 & 119427385 & 119427385 & A & G & Intron & - & rs45872254 \\
\hline & & 119427427 & 119427431 & TGCTC & - & Intron & - & - \\
\hline & & 119427489 & 119427489 & $\mathrm{C}$ & $\mathrm{T}$ & Exon & Synonymous SNV & rs254093865 \\
\hline & & 119427495 & 119427495 & $\mathrm{C}$ & $\mathrm{T}$ & Exon & Synonymous SNV & rs245957907 \\
\hline & & 119427867 & 119427867 & A & $\mathrm{C}$ & Intron & - & rs50502574 \\
\hline & & 119427874 & 119427874 & A & G & Intron & - & rs214816821 \\
\hline & & 119427922 & 119427922 & $\mathrm{~T}$ & G & Intron & - & rs238044625 \\
\hline & & 119427962 & 119427962 & $\mathrm{C}$ & $\mathrm{T}$ & Intron & - & rs48995394 \\
\hline & & 119428382 & 119428382 & A & G & Exon & Synonymous SNV & rs220947222 \\
\hline & & 119428430 & 119428430 & G & $\mathrm{C}$ & Exon & Synonymous SNV & rs236256586 \\
\hline
\end{tabular}




\begin{tabular}{|c|c|c|c|c|c|c|c|c|}
\hline & & 119428520 & 119428520 & A & G & Exon & Synonymous SNV & rs30372811 \\
\hline & & 119428612 & 119428612 & $\mathrm{C}$ & G & Intron & - & rs30134774 \\
\hline & & 119428620 & 119428620 & G & - & Intron & - & - \\
\hline & & 119429791 & 119429791 & - & A & Intron & - & - \\
\hline & & 119429811 & 119429811 & G & A & Intron & - & rs249216178 \\
\hline & & 119429889 & 119429889 & $\mathrm{C}$ & A & Exon & Synonymous SNV & rs50269096 \\
\hline & & 119429928 & 119429928 & $\mathrm{~T}$ & C & Exon & Synonymous SNV & rs231454902 \\
\hline & & 119430037 & 119430037 & G & A & Intron & - & rs215251161 \\
\hline & & 119430059 & 119430059 & A & G & Intron & - & rs50218863 \\
\hline & & 119430115 & 119430115 & - & ATAGTCAGAATCGCCACGCC & Intron & - & - \\
\hline & & 119430387 & 119430387 & $\mathrm{~T}$ & $\mathrm{C}$ & Intron & - & rs247262863 \\
\hline & & 119432888 & 119432888 & A & - & Intron & - & - \\
\hline Gnrh1 & chr14 & 67746552 & 67746552 & A & $\mathrm{T}$ & Intron & - & rs3023411 \\
\hline & & 67749359 & 67749359 & A & - & 3'UTR & - & - \\
\hline Lhcgr & chr17 & 88765044 & 88765044 & G & A & Exon & Synonymous SNV & rs45832892 \\
\hline & & 88765274 & 88765274 & G & A & Intron & - & rs49175256 \\
\hline & & 88765283 & 88765283 & $\mathrm{~T}$ & C & Intron & - & rs49233045 \\
\hline & & 88765284 & 88765284 & G & $\mathrm{C}$ & Intron & - & rs50445833 \\
\hline & & 88765297 & 88765297 & A & G & Intron & - & rs50723996 \\
\hline & & 88765328 & 88765328 & A & G & Intron & - & rs51548994 \\
\hline & & 88767223 & 88767223 & - & C & Intron & - & - \\
\hline & & 88767357 & 88767357 & G & C & Intron & - & rs33145242 \\
\hline & & 88767384 & 88767384 & A & C & Intron & - & rs33347120 \\
\hline & & 88769697 & 88769697 & $\mathrm{~T}$ & G & Intron & - & rs3717394 \\
\hline & & 88769748 & 88769748 & $\mathrm{~T}$ & A & Intron & - & rs3717517 \\
\hline
\end{tabular}

Page 26 of 31 


\begin{tabular}{|c|c|c|c|c|c|c|c|c|}
\hline & & 88769935 & 88769937 & AAC & - & Intron & - & rs235138678 \\
\hline & & 88772141 & 88772141 & G & A & Intron & - & rs52183165 \\
\hline & & 88792035 & 88792035 & $\mathrm{C}$ & $\mathrm{T}$ & Upstream & - & rs52233715 \\
\hline & & 88792040 & 88792040 & G & A & Upstream & - & rs52545123 \\
\hline \multirow[t]{16}{*}{$P g r$} & chr09 & 8900819 & 8900819 & $\mathrm{~T}$ & A & Exon & Non-synonymous SNV & rs16808507 \\
\hline & & 8900914 & 8900914 & A & $\mathrm{T}$ & Exon & Synonymous SNV & rs222662569 \\
\hline & & 8900959 & 8900959 & G & A & Exon & Synonymous SNV & rs246932498 \\
\hline & & 8901222 & 8901222 & G & A & Exon & Non-synonymous SNV & rs16808511 \\
\hline & & 8901259 & 8901259 & $\mathrm{C}$ & A & Exon & Synonymous SNV & rs16808515 \\
\hline & & 8901730 & 8901730 & $\mathrm{C}$ & G & Exon & Synonymous SNV & rs16808520 \\
\hline & & 8922762 & 8922762 & $\mathrm{C}$ & $\mathrm{T}$ & Intron & - & rs16808540 \\
\hline & & 8956132 & 8956132 & - & TGT & Intron & - & - \\
\hline & & 8956215 & 8956215 & $\mathrm{~T}$ & A & Intron & - & rs16808632 \\
\hline & & 8956228 & 8956228 & $\mathrm{~T}$ & - & Intron & - & rs16808634 \\
\hline & & 8956263 & 8956263 & $\mathrm{~T}$ & $\mathrm{C}$ & Exon & Synonymous SNV & rs16808635 \\
\hline & & 8956426 & 8956426 & A & G & Intron & - & rs38678743 \\
\hline & & 8956474 & 8956474 & G & A & Intron & - & rs253462664 \\
\hline & & 8956484 & 8956484 & $\mathrm{~T}$ & $\mathrm{C}$ & Intron & - & rs262156449 \\
\hline & & 8956517 & 8956517 & A & $\mathrm{C}$ & Intron & - & rs216472569 \\
\hline & & 8956530 & 8956530 & $\mathrm{C}$ & A & Intron & - & rs234992683 \\
\hline \multirow[t]{5}{*}{ Esr1 } & chr10 & 4964668 & 4964668 & G & A & Intron & - & rs29383782 \\
\hline & & 4964798 & 4964798 & C & $\mathrm{T}$ & Intron & - & rs50779278 \\
\hline & & 4964883 & 4964883 & $\mathrm{~T}$ & G & Intron & - & rs49862291 \\
\hline & & 4964886 & 4964886 & C & $\mathrm{T}$ & Intron & - & rs46991755 \\
\hline & & 4966154 & 4966154 & G & $\mathrm{T}$ & Intron & - & rs29315913 \\
\hline
\end{tabular}

Page 27 of 31 


\begin{tabular}{|c|c|c|c|c|c|c|}
\hline 4966407 & 4966407 & $\mathrm{~T}$ & $\mathrm{C}$ & Intron & - & rs29330062 \\
\hline 4969082 & 4969082 & A & G & Intron & - & rs16821149 \\
\hline 4969093 & 4969093 & G & A & Intron & - & rs16821150 \\
\hline 4969094 & 4969094 & $\mathrm{~T}$ & A & Intron & - & rs16821151 \\
\hline \multirow[t]{2}{*}{4969106} & 4969116 & TGTCTTC & - & Intron & - & rs214903150 \\
\hline & & GAGA & & & & \\
\hline 4969210 & 4969210 & G & $\mathrm{T}$ & Exon & Synonymous SNV & rs16821161 \\
\hline 4969249 & 4969249 & A & $\mathrm{T}$ & Exon & Synonymous SNV & rs47715549 \\
\hline 4969307 & 4969307 & $\mathrm{C}$ & $\mathrm{T}$ & Intron & - & rs46716572 \\
\hline 4969389 & 4969389 & $\mathrm{C}$ & $\mathrm{T}$ & Intron & - & rs47973744 \\
\hline
\end{tabular}

Table 2. Polymorphisms in luteinisation-related genes detected between the C57BL/6 and MRL/MpJ strains using next-generation sequencing

chr, chromosome; SNV, single nucleotide variant; Mmp2, matrix metalloproteinase 2; Mmp9: matrix metalloproteinase 9; UTR, untranslated region

\begin{tabular}{|c|c|c|c|c|c|c|c|c|}
\hline \multirow[t]{2}{*}{ Gene } & \multirow[t]{2}{*}{ Chr no. } & \multicolumn{2}{|c|}{ Location (bp) } & \multicolumn{2}{|c|}{ Strains } & \multirow[t]{2}{*}{ Region } & \multirow[t]{2}{*}{ Change } & \multirow[t]{2}{*}{ Variant ID } \\
\hline & & Start & End & C57BL/6 & MRL/MpJ & & & \\
\hline \multirow[t]{9}{*}{ Mmp2 } & chr08 & 92827509 & 92827509 & C & G & 5'UTR & - & rs50154992 \\
\hline & & 92827789 & 92827789 & $\mathrm{~T}$ & $\mathrm{C}$ & Intron & - & rs47915014 \\
\hline & & 92830595 & 92830595 & A & G & Intron & - & rs50707366 \\
\hline & & 92830606 & 92830606 & $\mathrm{~T}$ & A & Intron & - & rs47202868 \\
\hline & & 92830632 & 92830632 & C & $\mathrm{T}$ & Exon & Synonymous SNV & rs48669156 \\
\hline & & 92831599 & 92831602 & GCAC & - & Intron & - & - \\
\hline & & 92831611 & 92831611 & G & A & Intron & - & rs52544499 \\
\hline & & 92831862 & 92831862 & $\mathrm{~T}$ & $\mathrm{C}$ & Intron & - & rs47205486 \\
\hline & & 92832757 & 92832757 & A & G & Intron & - & rs45755812 \\
\hline
\end{tabular}




\begin{tabular}{|c|c|c|c|c|c|c|}
\hline 92832783 & 92832783 & A & G & Exon & Synonymous SNV & rs47346055 \\
\hline 92832906 & 92832906 & $\mathrm{C}$ & $\mathrm{T}$ & Intron & - & rs47940001 \\
\hline 92832935 & 92832935 & $\mathrm{~T}$ & C & Intron & - & rs46642227 \\
\hline 92832937 & 92832937 & $\mathrm{~T}$ & $\mathrm{C}$ & Intron & - & rs50670061 \\
\hline 92832983 & 92832983 & $\mathrm{~T}$ & C & Intron & - & rs51535272 \\
\hline 92833019 & 92833019 & $\mathrm{C}$ & $\mathrm{T}$ & Intron & - & rs46335818 \\
\hline 92833037 & 92833037 & G & $\mathrm{T}$ & Intron & - & rs50714352 \\
\hline 92833193 & 92833193 & $\mathrm{C}$ & $\mathrm{T}$ & Exon & Synonymous SNV & rs46421166 \\
\hline 92833273 & 92833273 & $\mathrm{C}$ & $\mathrm{T}$ & Intron & - & rs51678138 \\
\hline 92833286 & 92833286 & $\mathrm{~T}$ & $\mathrm{C}$ & Intron & - & rs 45705750 \\
\hline 92833302 & 92833302 & $\mathrm{~T}$ & $\mathrm{C}$ & Intron & - & rs50894680 \\
\hline 92835871 & 92835871 & A & G & Intron & - & rs45886546 \\
\hline 92835887 & 92835887 & A & G & Intron & - & rs46632834 \\
\hline 92835925 & 92835925 & $\mathrm{~T}$ & A & Intron & - & rs47396275 \\
\hline 92835947 & 92835947 & $\mathrm{~T}$ & $\mathrm{C}$ & Intron & - & rs48288639 \\
\hline 92835950 & 92835950 & $\mathrm{C}$ & A & Intron & - & rs45708441 \\
\hline 92835961 & 92835961 & $\mathrm{C}$ & - & Intron & - & - \\
\hline 92835994 & 92835994 & A & $\mathrm{T}$ & Exon & Synonymous SNV & rs47334964 \\
\hline 92836015 & 92836015 & $\mathrm{C}$ & $\mathrm{T}$ & Exon & Synonymous SNV & rs50617380 \\
\hline 92836072 & 92836072 & $\mathrm{~T}$ & $\mathrm{C}$ & Exon & Synonymous SNV & rs46039319 \\
\hline 92836120 & 92836120 & G & A & Exon & Synonymous SNV & rs50745645 \\
\hline 92836132 & 92836132 & $\mathrm{~T}$ & $\mathrm{C}$ & Exon & Synonymous SNV & rs49465794 \\
\hline 92836172 & 92836172 & A & G & Intron & - & - \\
\hline 92836208 & 92836208 & $\mathrm{~T}$ & $\mathrm{C}$ & Intron & - & rs50106637 \\
\hline 92836248 & 92836248 & A & $\mathrm{C}$ & Intron & - & rs50508247 \\
\hline
\end{tabular}




\begin{tabular}{|c|c|c|c|c|c|c|}
\hline 92837027 & 92837027 & G & A & Exon & Synonymous SNV & rs33504743 \\
\hline 92837149 & 92837149 & $\mathrm{~T}$ & $\mathrm{C}$ & Intron & - & rs46426201 \\
\hline 92839119 & 92839119 & $\mathrm{~T}$ & C & Intron & - & rs50615049 \\
\hline 92839341 & 92839341 & G & $\mathrm{T}$ & Exon & Synonymous SNV & rs46885156 \\
\hline 92839428 & 92839428 & A & C & Intron & - & rs47250679 \\
\hline 92840287 & 92840287 & - & $\mathrm{T}$ & Intron & - & - \\
\hline 92840355 & 92840355 & $\mathrm{~T}$ & G & Intron & - & rs47524903 \\
\hline 92840387 & 92840387 & $\mathrm{~T}$ & $\mathrm{C}$ & Intron & - & rs48300311 \\
\hline 92840400 & 92840400 & C & $\mathrm{T}$ & Exon & synonymous SNV & rs46870953 \\
\hline 92840436 & 92840436 & A & G & Exon & Synonymous SNV & rs51331853 \\
\hline 92840440 & 92840440 & C & $\mathrm{T}$ & Exon & Synonymous SNV & rs51553188 \\
\hline 92840567 & 92840567 & A & $\mathrm{T}$ & Intron & - & - \\
\hline 92840621 & 92840621 & A & G & Intron & - & rs49727866 \\
\hline 92843814 & 92843814 & $\mathrm{~T}$ & $\mathrm{C}$ & Intron & - & rs32814582 \\
\hline 92844028 & 92844028 & $\mathrm{~T}$ & $\mathrm{C}$ & Intron & - & rs45701744 \\
\hline 92846032 & 92846032 & G & $\mathrm{T}$ & Intron & - & rs48669406 \\
\hline 92846077 & 92846077 & $\mathrm{~T}$ & $\mathrm{C}$ & Intron & - & rs51010704 \\
\hline 92846106 & 92846106 & $\mathrm{~T}$ & $\mathrm{C}$ & Exon & Synonymous SNV & rs46518220 \\
\hline 92846109 & 92846109 & $\mathrm{~T}$ & $\mathrm{C}$ & Exon & Synonymous SNV & rs46528268 \\
\hline 92846265 & 92846265 & C & $\mathrm{T}$ & Intron & - & rs33044164 \\
\hline 92846284 & 92846284 & C & A & Intron & - & rs49358673 \\
\hline 92846296 & 92846304 & ATGTGGCTT & - & Intron & - & - \\
\hline 92846309 & 92846309 & $\mathrm{~T}$ & G & Intron & - & rs240469150 \\
\hline 92846340 & 92846340 & $\mathrm{~T}$ & A & Intron & - & rs50419882 \\
\hline 92846341 & 92846341 & $\mathrm{~T}$ & $\mathrm{C}$ & Intron & - & rs50984607 \\
\hline
\end{tabular}




$\begin{array}{ccccccrr} & 92850078 & 92850078 & \text { G } & \text { A } & \text { Intron } & - & \text { rs46081866 } \\ & 92850156 & 92850156 & \text { C } & \text { G } & \text { Exon } & \text { Synonymous SNV } & \text { rs49302213 } \\ & 92850213 & 92850213 & \text { C } & \text { T } & \text { Exon } & \text { Synonymous SNV } & \text { rs48609021 } \\ & 92850231 & 92850231 & \text { T } & \text { C } & \text { Exon } & \text { Synonymous SNV } & \text { rs51146338 } \\ & 92852461 & 92852461 & \text { C } & \text { T } & \text { Intron } & - & \text { rs49769472 } \\ & 92852477 & 92852477 & \text { A } & \text { G } & \text { Intron } & - & \text { rs46075410 } \\ & 92852508 & 92852508 & \text { C } & \text { A } & \text { Intron } & \text { rs1124308 } \\ & \text { Mmp9 chr02 } & 164953375 & 164953375 & \text { T } & \text { C } & \text { Exon } & \text { Non-synonymous SNV }\end{array}$


PMSG injection

Sperovulation treatment Hours post ovulation (h.p.o.)

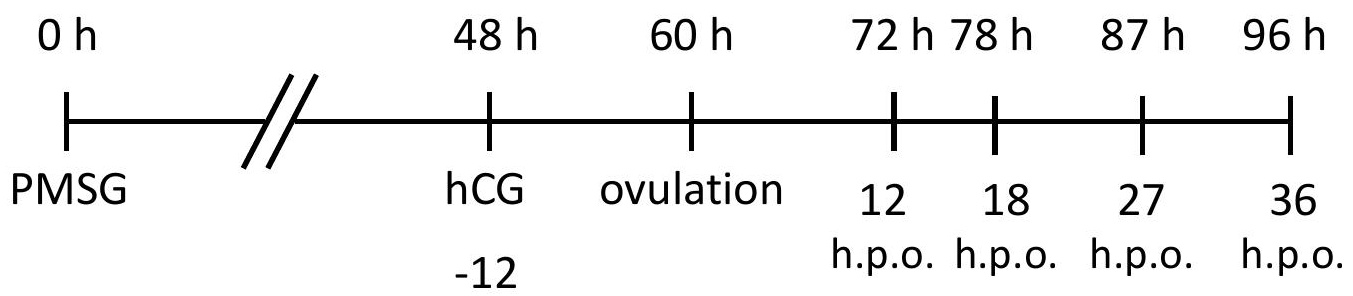

h.p.o. 
Fertilised

embryos

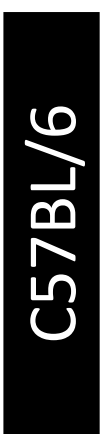

a

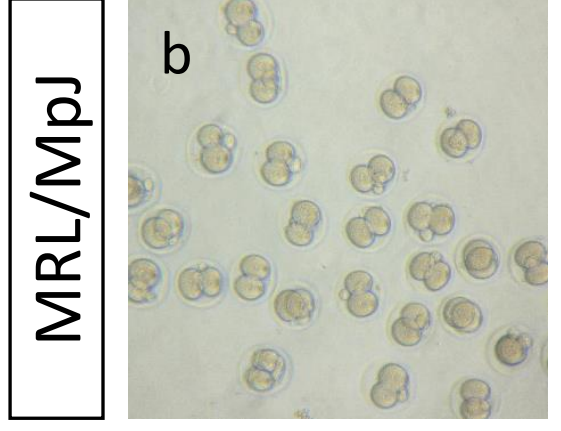

Dead

embryos

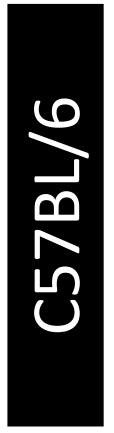

$\sum_{\substack{\underline{\alpha} \\ \Sigma}}^{\frac{\partial}{\Sigma}}$

g
Unfertilised embryos

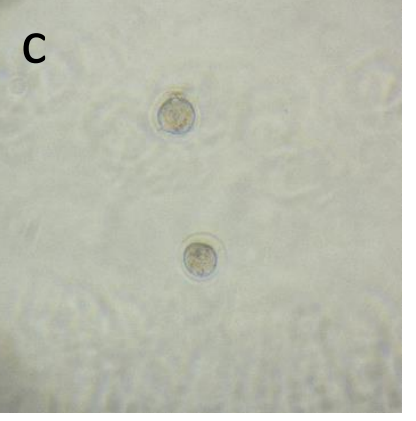

d

Oocytes in antral follicle
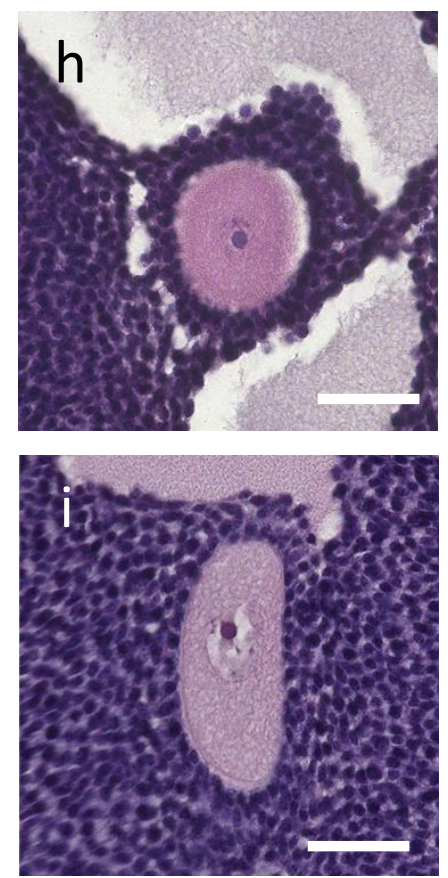

Abnormal

cleavage

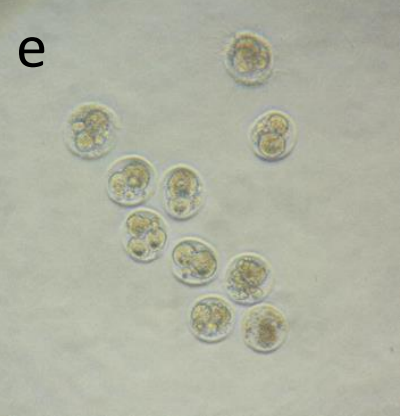

f

j

Oocyte aspect ratio

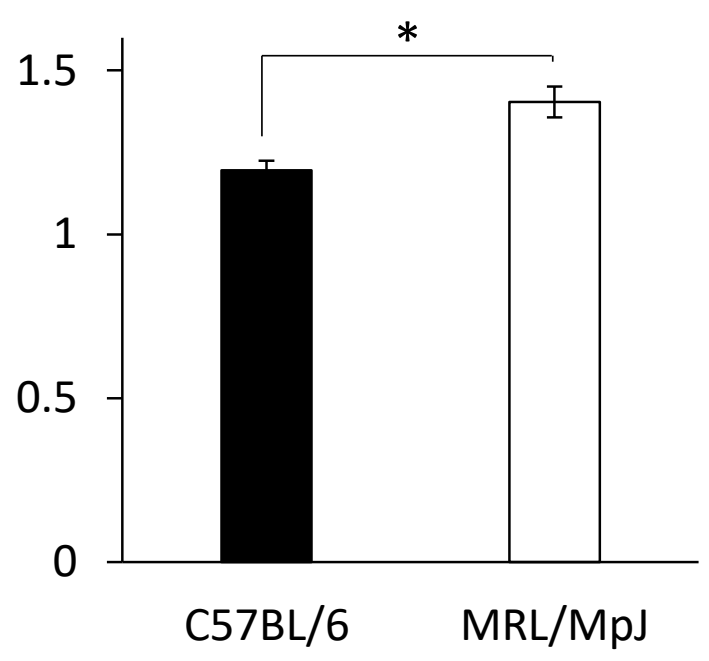




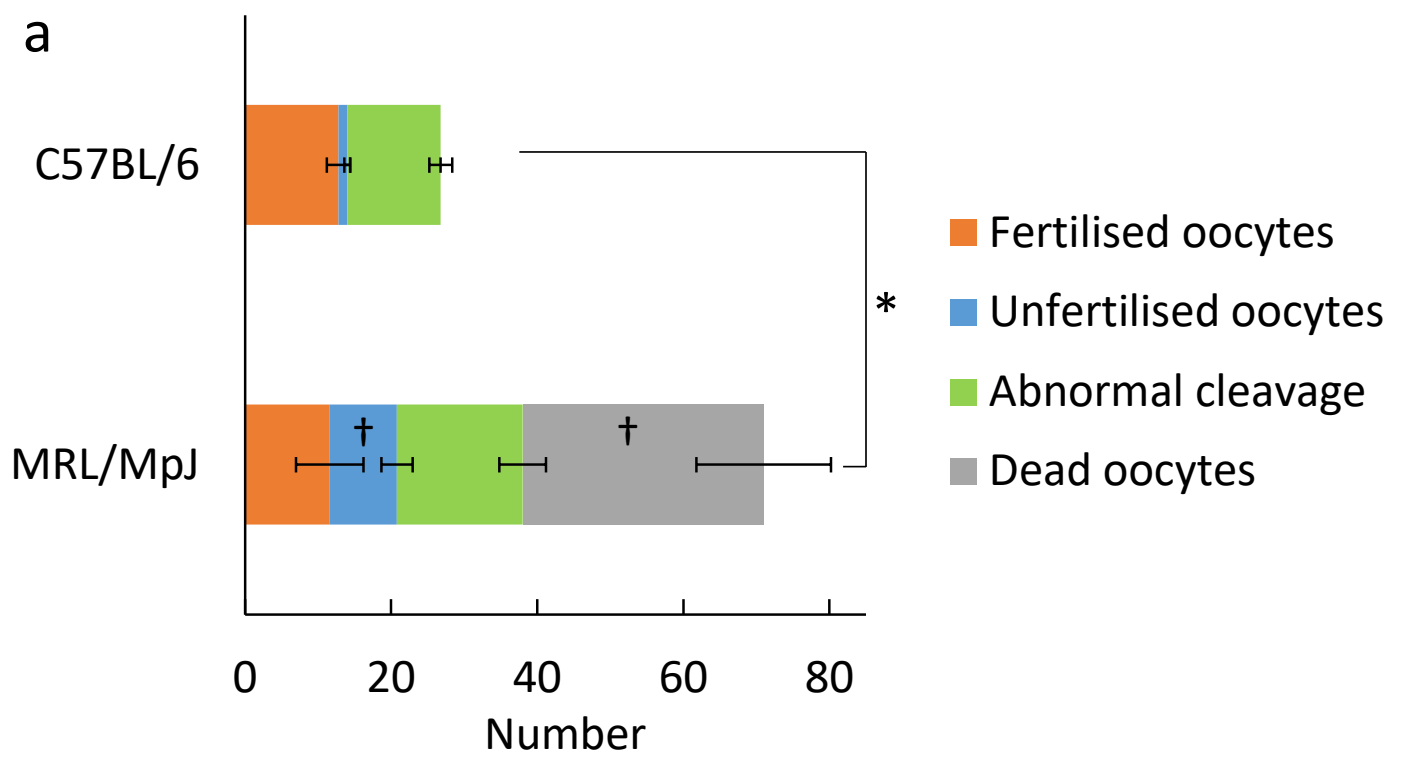

b

Fertilisation rate

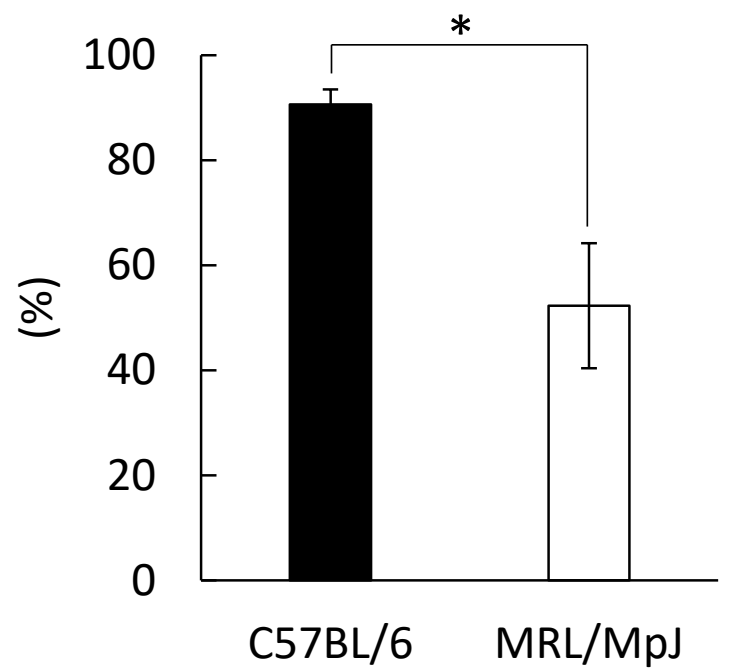


a

Naturally ovulated COCs

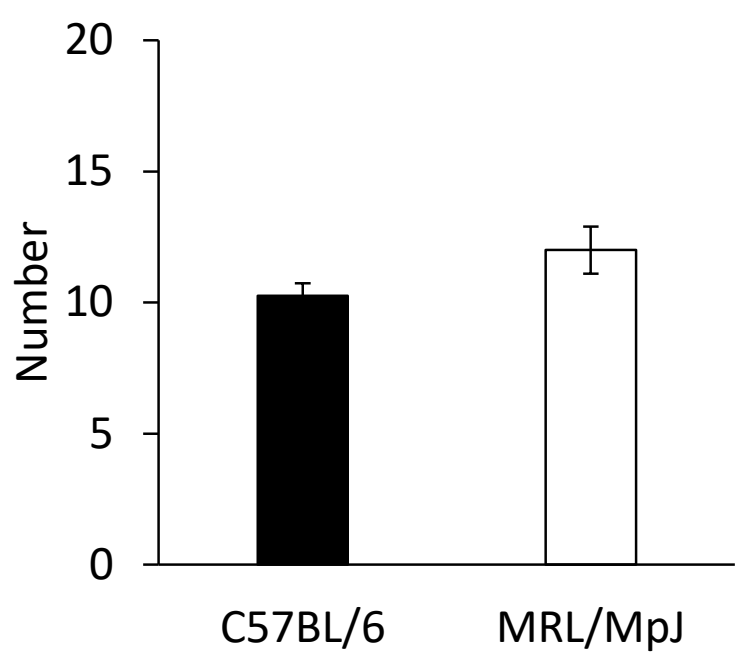

c COCs ovulated by hCG

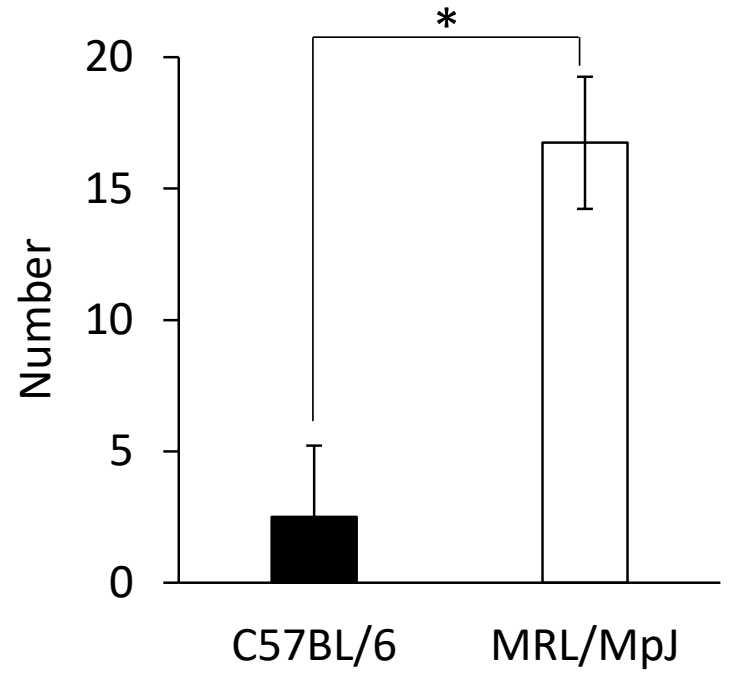

b COCs ovulated by PMSG

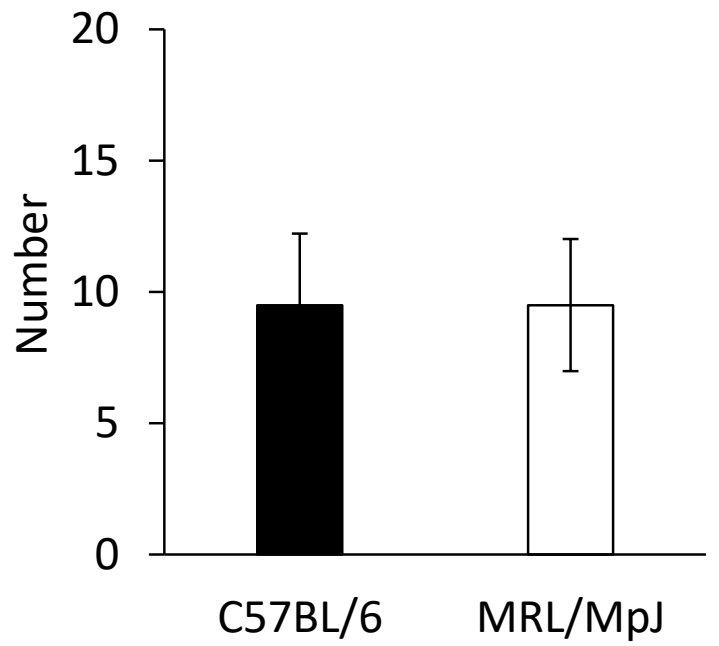




\section{C57BL/6}
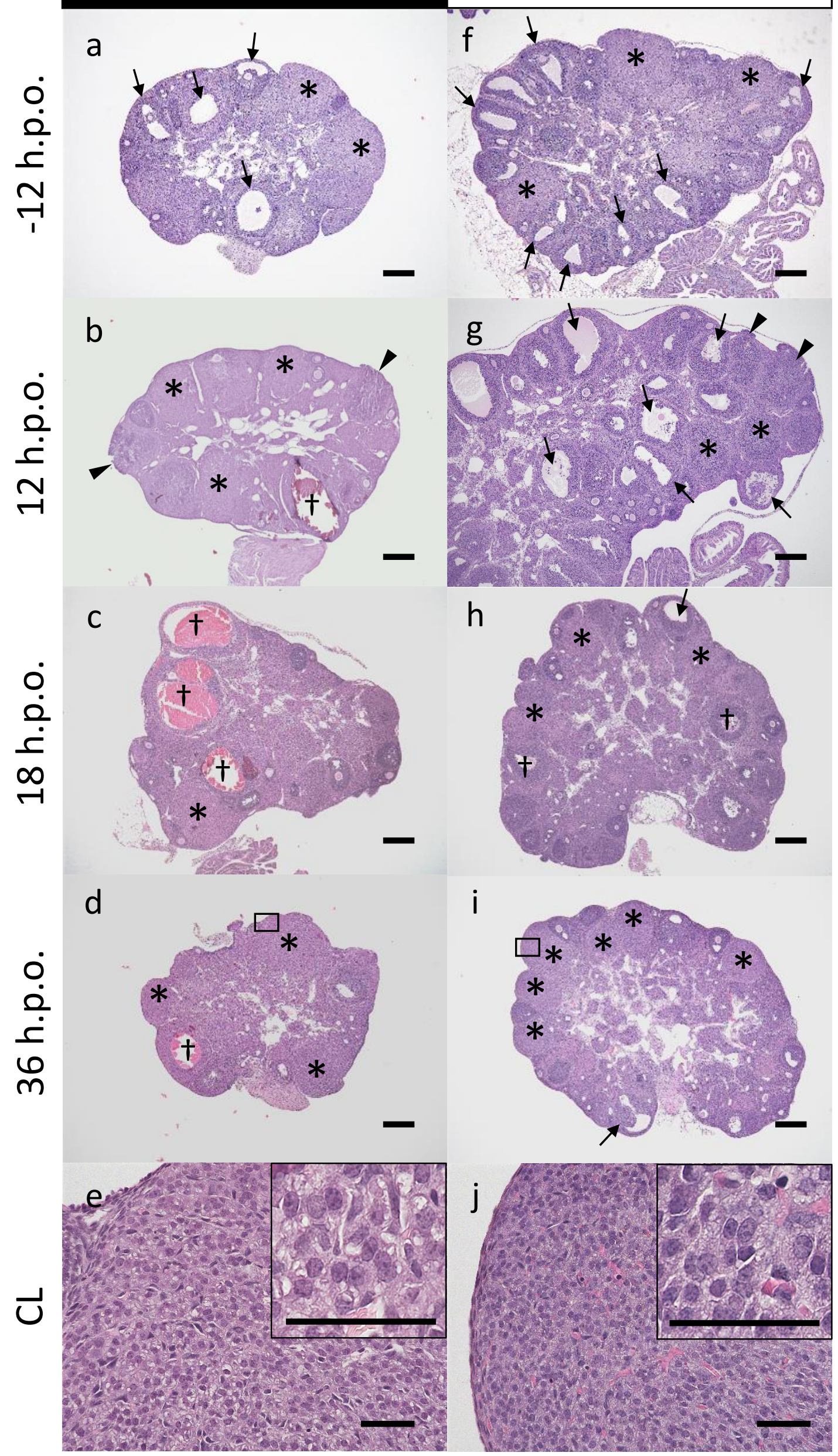
a $\mathrm{C} 57 \mathrm{BL} / 6$
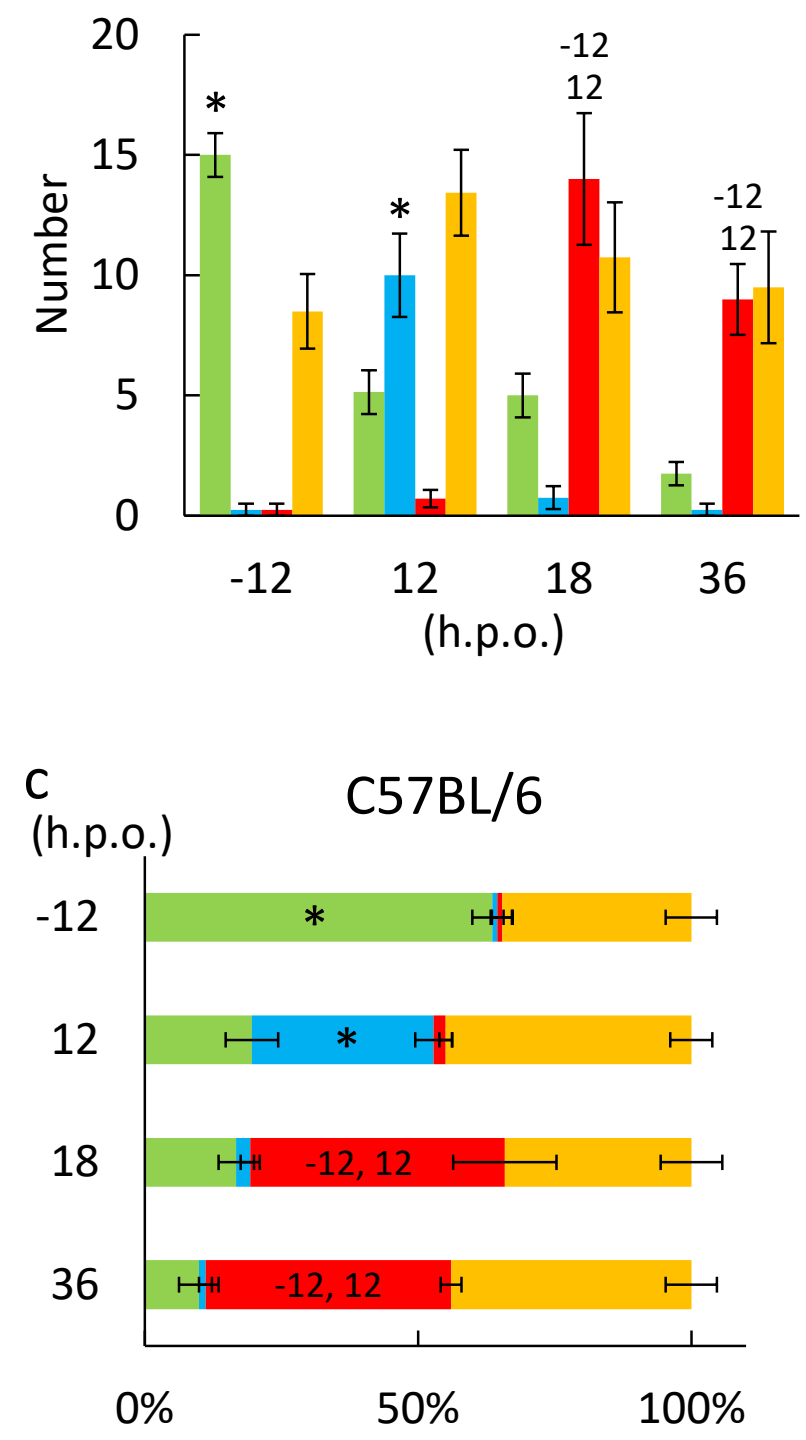

b

$\mathrm{MRL} / \mathrm{MpJ}$
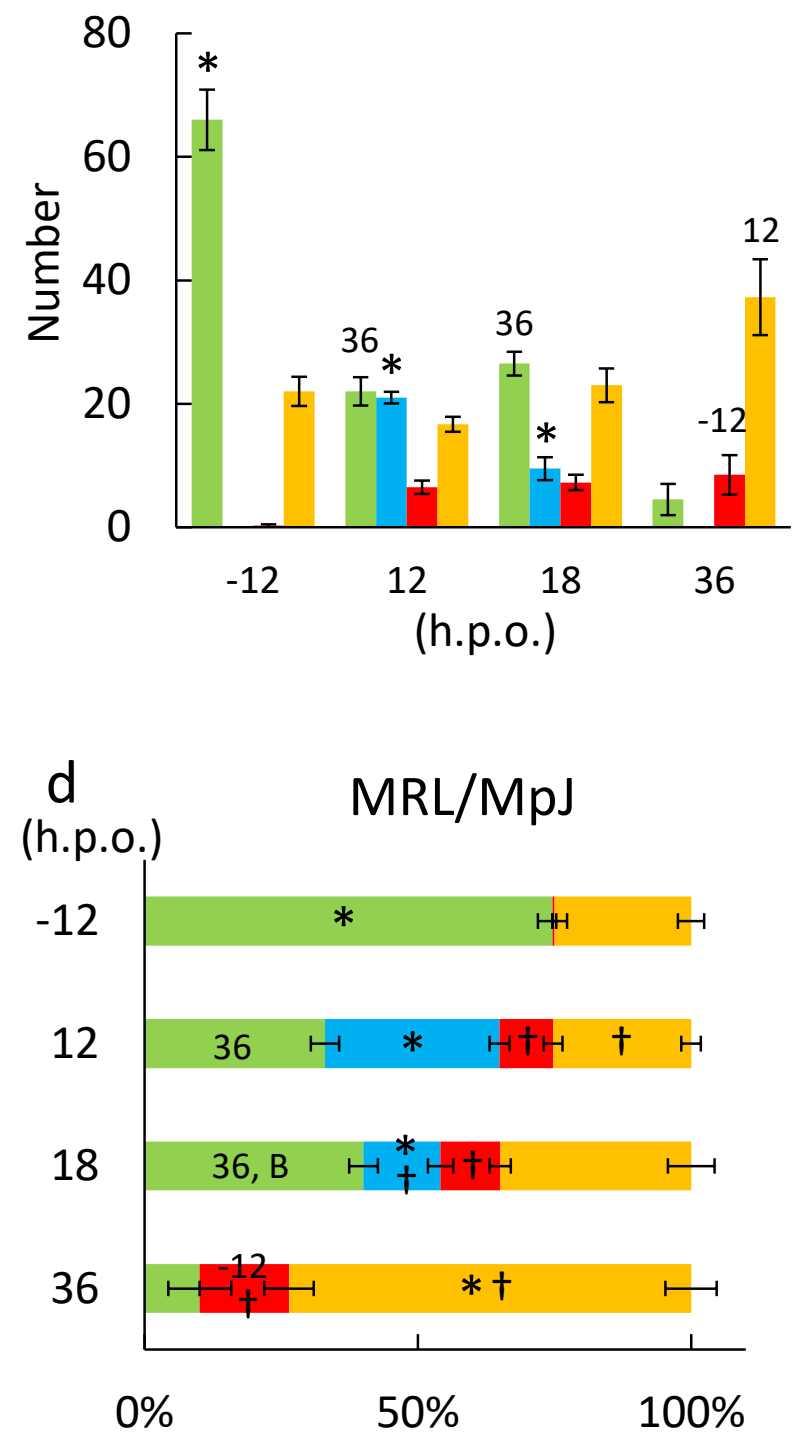

Antral follicle $\square$ Ruptured follicle $\square$ Corpus hemorrhagicum $\square$ Corpus luteum 

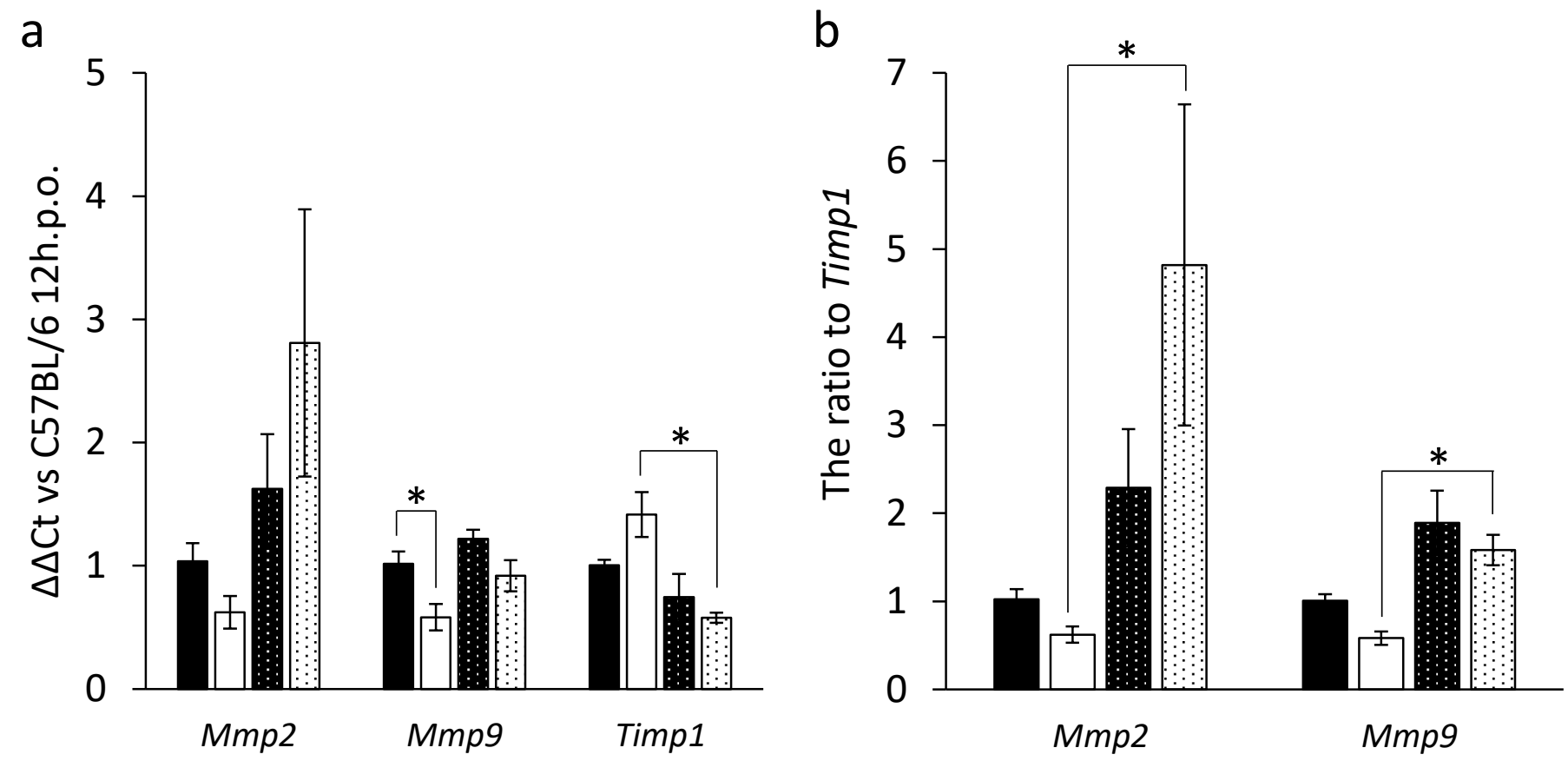

- C57BL/6 12h.p.o. $\square$ MRL/MpJ 12h.p.o. C57BL/6 27h.p.o. $\square$ MRL/MpJ 27h.p.o. 